Article

\title{
Distribution of Phenolic Compounds and Antioxidant Activity in Plant Parts and Populations of Seven Underutilized Wild Achillea Species
}

\author{
Lina Raudone ${ }^{1,2, *(\mathbb{D}}$, Jolita Radušiene ${ }^{3} \mathbb{D}$, Fatih Seyis ${ }^{4}\left(\mathbb{D}\right.$, Fatih Yayla ${ }^{5}$, Gabrielè Vilkickyte ${ }^{2} \mathbb{D}$, \\ Mindaugas Marksa ${ }^{6}$ (D), Liudas Ivanauskas ${ }^{6}$ and Cüneyt Crrak $^{7}$
}

\section{check for}

updates

Citation: Raudone, L.; Radušiene, J.; Seyis, F.; Yayla, F.; Vilkickyte, G.;

Marksa, M.; Ivanauskas, L.; Cirak, C. Distribution of Phenolic Compounds and Antioxidant Activity in Plant Parts and Populations of Seven Underutilized Wild Achillea Species. Plants 2022, 11, 447. https://doi.org/ $10.3390 /$ plants 11030447

\section{Academic Editor:}

Antonella Smeriglio

Received: 13 January 2022

Accepted: 2 February 2022

Published: 6 February 2022

Publisher's Note: MDPI stays neutral with regard to jurisdictional claims in published maps and institutional affiliations.

Copyright: (c) 2022 by the authors. Licensee MDPI, Basel, Switzerland. This article is an open access article distributed under the terms and conditions of the Creative Commons Attribution (CC BY) license (https:// creativecommons.org/licenses/by/ $4.0 /)$.

1 Department of Pharmacognosy, Lithuanian University of Health Sciences, Sukileliu Av. 13, 50162 Kaunas, Lithuania

2 Laboratory of Biopharmaceutical Research, Institute of Pharmaceutical Technologies, Lithuanian University of Health Sciences, Sukileliu Av. 13, 50162 Kaunas, Lithuania; gabriele.vilkickyte@lsmu.lt

3 Institute of Botany, Nature Research Center, Akademijos Str. 2, 08412 Vilnius, Lithuania; jolita.radusiene@gamtc.lt

4 Department of Field Crops, Faculty of Agriculture and Natural Sciences, Recep Tayyip Erdoğan University, 53100 Rize, Turkey; fatih.seyis@erdogan.edu.tr

5 Department of Biology, Faculty of Arts and Sciences, Gaziantep University, 27310 Gaziantep, Turkey; fyayla@gantep.edu.tr

6 Department of Analytical and Toxicological Chemistry, Lithuanian University of Health Sciences, Sukileliu Av. 13, 50162 Kaunas, Lithuania; mindaugas.marksa@lsmuni.lt (M.M.); liudas.ivanauskas@1smuni.lt (L.I.)

7 Bafra Vocational School, Ondokuz Mayis University, Atacum, 55200 Samsun, Turkey; kalinor27@gmail.com

* Correspondence: lina.raudone@lsmuni.lt

\begin{abstract}
Evaluation of phytochemical composition of underutilized Achillea species provides the primary selection of germplasms with the desired quality of raw material for their further applications. The aim of the study was to evaluate the comprehensive distribution patterns of phenolic compounds in seven wild Achillea spp. and their plant parts, and to assess their antioxidant activity. Plant material was collected from different sites in Turkey. A complex of hydroxycinnamic acids, flavonols and flavones was identified and quantified in methanolic extracts using HPLC-PDA method. Antioxidant activity was assessed by radical scavenging assay. The results showed that qualitative and qualitative profiles of caffeoylquinic acids and flavonoids were species-specific, explaining the characteristic patterns of their variation in the corresponding species and plant parts. The highest total amount of caffeoylquinic acids was detected in A. setacea. A. arabica exposed the highest accumulation of monocaffeoylquinic acids and flavonoids with the greatest levels of quercetin and luteolin derivatives and the flavonol santin. Santin was detected in all plant parts of A. cappadocica, A. setacea, A. santolinoides subsp. wilhelmsii, and $A$. arabica. A notable antiradical capacity was confirmed in A. arabica, A. setacea and $A$. cappadocica plant extracts. The leaves of all studied species were found to have priority over inflorescences and stems in terms of radical scavenging activity. The new data complemented the information that may be relevant for the continuation of chemophenetic studies in the heterogeneous genus Achillea.
\end{abstract}

Keywords: Achillea species; phenolic profile; antioxidant activity; interspecific diversity

\section{Introduction}

The increasing trend in use of natural products or natural product derivatives is leading to a growing demand for standardized, homogeneous raw materials in industry, which means that more and more wild species have been domesticated and systematically cultivated. On the other hand, the International Standard for Sustainable Wild Collection of Medicinal and Aromatic Plants (ISSC-MAP) certifies the conservation and use of plant 
biodiversity, avoiding overharvesting leading to genetic erosion and habitat loss, but these provisions have been considered in the context of economically sustainable use of plant resources. The selection of germplasm from wild populations with commercially desirable traits is the primary approach that can provide opportunities for the selection and development of medicinal plants as crops, as well as to reduce harvesting pressure on wild populations. Cultivated plant material has a number of advantages over wild harvest, in particular reliable botanical identification, a narrow genetic range, and the quality control and standardization of materials can be adapted to the regulations and consumer preferences [1]. Therefore, the assessment of phytochemical composition of wild plant raw material sources is the reason of the primary selection of economically important medicinal plant germplasms with the desired quality of raw material for their further domestication and cultivation.

The genus Achillea L. of the Asteraceae family, depending on the species definition, includes about 110-140 species [2] and provides a high potential of underutilized plant resources. Turkey is the largest Achillea species distribution region with 69 identified species, 33 of which are endemic [3]. Achillea species are one of the oldest medicinal plants used in folk and traditional medicine in various countries as a natural remedy for the treatment of wounds, bleedings, gastrointestinal disorders, headache, inflammation, pains, and spasmodic diseases [4]. The use of Achillea spp. is highly important in Persian and Anatolian folk herbal medicines for the treatment of various disorders [5]. The ethnopharmacological information is further developed in the selection of species with the potential to be used in pharmaceuticals. Despite the great diversity of Achillea spp., only A. millefolium L., commonly known as "yarrow", is worldwide recognized as a medicinal raw material. Plant material of flowering tops (Millefolii herba) is recorded in a number of monographs of the European National Pharmacopoeias and described in the report of the European Medicines Agency as an herbal medicine [6,7]. In this way, the growing industrial demand for raw materials is a major challenge to explore the wide diversity of underutilized Achillea spp. and to find alternative sources that have could be valuable in the pharmaceutical, cosmeceutical or food industries. There is strong scientific evidence that other species of yarrow might be rich sources of bioactive ingredients. Scientific experimental and clinical studies have confirmed the various therapeutic activities in different Achillea species such as antimicrobial, anti-inflammatory, cytotoxic, antinociceptive, anti-inflammatory, wound healing, estrogenic, and antispasmodic, hepatoprotective and choleretic. [8].

Achillea arabica Kotschy, together with A. millefolium, is the most common species of genus in Turkish flora. In most of the previous sources, $A$. arabica was referred by a taxonomic synonym for $A$. biebersteinii Afan. ex Hub.-Mor., which was described later, so the first name for the corresponding taxon, A. arabica, was adopted [9]. The therapeutic potency of A. arabica as a medicinal plant has been recognized and documented in various pharmacological studies as an alternative in the treatment of endometriosis [10], wound healing [10-12], and was considered as a promising anticancer agent for the treatment of colon cancer [13]. A. biebersteinii hydroglycolic extract has been displayed significant antiradical, tyrosinase inhibiting and sun protective properties as an active ingredient in cosmetics [14]. A. wilhelmsii K.Koch, a synonym of accepted name A. santolinoides subsp. wilhelmsii (K.Koch) Greuter [15], has been shown to have antihyperlipidemic, antihypertensive, and antimycobacterial properties [16], and has potential for the treatment of indomethacin-induced gastric ulcers [17]. The treatment with $A$. wilhelmsii hydroalcoholic extract significantly reduced triglycerides, total cholesterol, and low-density lipoproteins, and reduced diastolic and systolic blood pressure [18]. A. wilhelmsii leaf and stem extracts induced antiproliferative and apoptotic effects on prostate cancer cell lines [19]. Gevrenova et al. [20] detected that extracts of A. santolinoides and A. allepica DC. areal parts and roots significantly inhibited butyrylcholinesterase and tyrosinase, suggesting the potential applications of these plants in cosmetics, pharmaceuticals, and nutraceuticals products. A. coarctata Poir. extracts showed cytotoxic activity on human breast cancer cell lines, while essential oil had antimicrobial activity against several pathogenic microorganisms $[20,21]$. 
The lypophilic extract of $A$. setacea showed hemostatic activity in the case of toxic animal hepatitis [22]. A literature survey revealed that there is only one report on the endemic A. cappadocica Hausskn. \& Bornm., which showed some antioxidant, anticholinesterase, antimicrobial activity of the extract [23]. Numerous studies on the composition and biological activities of essential oils have been performed on $A$. biebersteinii, A. wilhelmsii, $A$. setacea, and $A$. coarctata $[21,24,25]$. The biological and pharmacological activities of Achillea spp. were mainly attributed to the variable compounds of essential oils and polyphenolic compounds with the highest importance of azulenogenous sesquiterpene lactones, flavonoids and phenolic acids [26,27]. Moreover, the chemical profile and biological effects of different species and their plant parts vary greatly [28]. Therefore, it is of crucial importance to identify differences in extracts to obtain consistent and targeted biological test results. Recently, much attention has been paid to towards phenolic acids and flavonoids, which are considered to be high important biologically active compounds in Achillea spp. with strong antioxidant effects [29-32]. However, data on the qualitative and quantitative phenolic profiles of Achillea spp. are scarce. Moreover, the chemical profiles and biological effects of raw materials vary greatly between different species and their plant parts [28]. Therefore, it is essential to identify differences in the profiles of plant extracts to obtain consistent and validated results for further biological tests. The study aimed to provide a comparative assessment of the diversity of phenolic profiles and their antioxidant activity of seven underutilized Achillea spp. for reasonably further evaluation by selecting the desired germplasm. To the best of our knowledge, the comprehensive patterns for the distribution of phenolic compounds in wild populations of seven Achillea spp. and their plant parts have been determined for the first time. The obtained results will complement the knowledge on phenolic profiles and species diversity in the genus Achillea.

\section{Results}

\subsection{Phenolic Profiles of Leaves, Inflorescences, and Stems across Achillea Species}

A complex of hydroxycinnamic acids, flavonols and flavones was detected in the leaves, inflorescences, and stems of the seven wild Achillea species (Tables 1-3). Chemical profiles of Achillea spp. varied according to the amounts of individual compounds and their distribution among plant parts. Significant differences were found in the accumulation of all compounds among the seven species and their leaves, inflorescences, and stems, with the exception of neochlorogenic acid in the leaves and inflorescences, apigenin in the leaves and 3.5-dicaffeoylquinic acid in the stems. On average, caffeoylquinic acids comprised about $77 \%$ of total identified phenolic compounds in the profiles of wild Achillea species. The highest total amount of all identified caffeoylquinic acids was detected in $A$. setacea leaf, inflorescence, and stem samples, 25,842.38, 11,913.84 and $4696.72 \mu \mathrm{g} / \mathrm{g}$, respectively. Differently from other species, $A$. arabica accumulated higher amounts of flavonoids than caffeoylquinic acids. The amount of total identified caffeoylquinic acids in the leaf and inflorescence samples of investigated species can be presented in the following decreasing order: A. setacea $>$ A. arabica $\sim$ A. coarctata $>$ A. aleppica $>$ A. cappadocica $>A$. santolinoides $>$ A. santolinoides subsp. wilhelmsii. However, the amounts of caffeoylquinic acid in stem samples did not follow this trend. Moreover, caffeoylquinic acids, namely chlorogenic, 3,4-dicaffeoylquinic acid, 3,5-dicaffeoylquinic acid and 4,5-dicaffeoylquinic acid, were the predominant compounds in leaves, inflorescences, and stems, with significant quantitative changes between species. Significantly the highest $(p<0.05)$ content of chlorogenic acid was found in $A$. arabica leaves and $A$. setacea inflorescences, 3,5-dicaffeoylquinic acid predominated in $A$. cappadocica and $A$. setacea leaf and inflorescence samples, while 3,4dicaffeoylquinic acid prevailed in all parts of $A$. setacea. Meanwhile, the significantly highest content of 4,5-dicaffeoylquinic acid was detected in $A$. coarctata leaf and inflorescence samples. In addition, more notable levels of neochlorogenic acid were detected in the leaves of A. aleppica and A. arabica. Achillea spp. accumulated minor contents of 1,5-O-dicaffeoylquinic and caffeic acids in all plant parts. Consequently, depending on the prevailing caffeoylquinic acid, the species can be divided into three groups. One group 
combined A. aleppica, A. santolinoides subsp. wilhelmsii, and $A$. arabica species, which were dominated by chlorogenic acid. Meanwhile, $A$. cappadocica, A.setacea, and $A$. santolinoides were prevailed by 3,5-dicaffeoylquinic acid, while $A$. coarctata was dominated by both 4,5-dicaffeoylquinic and 3,5-dicaffeoylquinic acids. Thus, the studied species differed in their quantitative profiles of mono- and dicaffeoylquinic acids. The mode of species-specific profiles of caffeoylquinic acids showed significant quantitative differences between plant parts, the amount of which predominated in the leaves. The quantitative variation of caffeoylquinic acids in the stems correspondent weakly to the patterns determined in the leaves and inflorescences, nevertheless, chlorogenic acid and 3,5-dicaffeoylgquinic acid remained the predominant compounds in all stems of Achillea spp. tested.

The flavonol complex consisted of quercetin and its derivatives, namely quercitrin, rutin, isoquercitrin, and methylated flavonol santin. Notable amounts of quercitrin were detected in A. arabica leaf, inflorescence, and stem samples, accounting for $8904.9 \pm 5126.48 \mu \mathrm{g} / \mathrm{g}, 8487.21$ $\pm 3445.28 \mu \mathrm{g} / \mathrm{g}$ and $2442.38 \pm 1407.88 \mu \mathrm{g} / \mathrm{g}$, respectively, whereas other species did not accumulate this compound at all. Santin was detected in all plant parts of $A$. cappadocica, A. setacea, A. santolinoides subsp. wilhelmsii, and A. arabica. Leaf and inflorescences of $A$. setacea differed significantly with the highest amounts of santin, $784.02 \pm 287.25 \mu \mathrm{g} / \mathrm{g}$ and $548.80 \pm$ $190.9 \mu \mathrm{g} / \mathrm{g}$, respectively. Meanwhile, santin was not detected in A. aleppica, A. coarctata and A. santolionides. Rutin was found in all plant parts of all tested species, except for $A$. aleppica raw materials, in which this compound was not detected. The amounts of isoquercitrin varied significantly within the species and their plant parts, with the highest levels in $A$. arabica inflorescences and leaves.

The identified flavones were luteolin, apigenin and their glucosides. Luteolin-7glucoside was the only flavone compound found in all species tested and their plant parts. The highest levels of this compound were accumulated in A. arabica, which ranged from 198.55 in stems to $5646.13 \mu \mathrm{g} / \mathrm{g}$ in inflorescences. The highest amounts of luteolin derivatives were found in the inflorescences of A. arabica, A. santolinoides, and A. setacea. Overall, the pattern of caffeoylquinic acid and flavonoid profiles showed significant quantitative differences between species and plant parts that predominated in the leaves compared to the inflorescences and stems. All species except $A$. arabica were dominated by accumulation of caffeoylquinic acids, with the highest total content in $A$. setacea. Achillea setacea, $A$. coarctata and $A$. cappadocica were prevailed by dicaffeoylquinic acids, while $A$. arabica and $A$. aleppica by mono-caffeoylquinic acids. Achillea arabica was distinguished by an exceptional quantitative profile of flavonoids, with the highest content of quercetin and luteolin derivatives compared to other species. In addition, A. arabica raw materials distinguished the highest total amount of all detected compounds, averaging 23,511.9, 38,180.5, and $8124.4 \mu \mathrm{g} / \mathrm{g}$, in leaf, inflorescence and stem samples, respectively. Meanwhile, A. aleppica plant raw materials accumulated the lowest amounts of all identified flavonoids. 
Table 1. Mean quantities ( $\mu \mathrm{g} / \mathrm{g}, \mathrm{DM})$ of phenolic compounds in leaves of Achillea spp. and their multivariate comparison among seven wild species.

\begin{tabular}{|c|c|c|c|c|c|c|c|c|}
\hline Compounds & A. cappadocica & A. setacea & A. aleppica & A. coarctata & $\begin{array}{l}\text { A.santolinoides } \\
\text { subsp. wilhelmsii }\end{array}$ & A. santolinoides & A. arabica & $p$-Value \\
\hline Neochlorogenic acid & ${ }^{1} 608.73 \pm 156.58$ & $728.7 \pm 111.15$ & $1683.2 \pm 84.16$ & $378 \pm 18.9$ & $935.4 \pm 216.89$ & $519.4 \pm 14.99$ & $1824.28 \pm 1013.49$ & 0.21 \\
\hline Chlorogenic acid & $3347.2 \pm 944.48^{\mathrm{ab} 1}$ & $8062.76 \pm 1279.67^{a b c}$ & $10,020.3 \pm 501.02 \mathrm{bc}$ & $1973.4 \pm 98.67^{\mathrm{a}}$ & $4871.02 \pm 1666.55^{\mathrm{ab}}$ & $4038.2 \pm 116.57^{a b}$ & $12,884.98 \pm 4288.21^{c}$ & $<0.05$ \\
\hline 4-caffeoylquinic acid & $193.47 \pm 46.78^{a b}$ & $996.4 \pm 368.42^{b}$ & $873.1 \pm 43.66^{\mathrm{ab}}$ & $139.6 \pm 6.98^{a}$ & $508.56 \pm 134.31 \mathrm{ab}$ & $231.8 \pm 6.69 \mathrm{ab}$ & $619.5 \pm 282.72 \mathrm{ab}$ & $<0.05$ \\
\hline 3,4-dicaffeoylquinic acid & $2020.63 \pm 627.73^{a b}$ & $3399.46 \pm 1211^{b}$ & $683.2 \pm 34.16^{\mathrm{a}}$ & $1722.2 \pm 86.11^{\mathrm{ab}}$ & $570.72 \pm 177.14^{\mathrm{a}}$ & $2328.8 \pm 67.23^{a b}$ & $787.68 \pm 583.73^{a}$ & $<0.05$ \\
\hline 3,5-dicaffeoylquinic acid & $7564.07 \pm 2067.07 \mathrm{ab}$ & $11,570.64 \pm 2836.29^{b}$ & $2758.8 \pm 137.94^{\mathrm{a}}$ & $6615.3 \pm 330.77$ ab & $2451.38 \pm 853.18^{a}$ & $5012.2 \pm 144.69 \mathrm{ab}$ & $4662.28 \pm 3081.53^{\mathrm{ab}}$ & $<0.05$ \\
\hline 1,5-dicaffeoylquinic acid & $396.03 \pm 79.37^{b}$ & $21.54 \pm 21.54^{\mathrm{a}}$ & $0 \pm 0^{\mathrm{a}}$ & $750.4 \pm 37.52^{c}$ & $25.98 \pm 16.93^{a}$ & $404.7 \pm 11.68^{b}$ & $114.28 \pm 90.28^{\mathrm{a}}$ & $<0.001$ \\
\hline 4,5-dicaffeoylquinic acid & $1232.77 \pm 469.86^{\mathrm{a}}$ & $1062.88 \pm 454.86^{\mathrm{a}}$ & $378.8 \pm 18.94^{\mathrm{a}}$ & $6615.3 \pm 330.77^{b}$ & $299.82 \pm 90.24^{\mathrm{a}}$ & $1210.6 \pm 34.95^{\mathrm{a}}$ & $245.5 \pm 141.07^{\mathrm{a}}$ & $<0.001$ \\
\hline Caffeic acid & $34.47 \pm 6.73^{\mathrm{b}}$ & $33.56 \pm 11.64^{b}$ & $0.7 \pm 0.04^{\mathrm{a}}$ & $21.1 \pm 1.06^{\mathrm{ab}}$ & $24.86 \pm 6.44^{\mathrm{ab}}$ & $83.6 \pm 2.41^{c}$ & $11.58 \pm 6.84^{\mathrm{ab}}$ & $<0.001$ \\
\hline Rutin & $1785.07 \pm 476.65^{\mathrm{abc}}$ & $932.56 \pm 531.04 \mathrm{ab}$ & $0 \pm 0^{a}$ & $3137.4 \pm 156.87^{c}$ & $130.08 \pm 109.22 \mathrm{ab}$ & $1019.3 \pm 29.42^{\mathrm{ab}}$ & $2115.63 \pm 1284.52^{b c}$ & $<0.05$ \\
\hline Quercetin & $15.8 \pm 7.9^{\mathrm{a}}$ & $23.34 \pm 5.97^{\mathrm{ab}}$ & $0 \pm 0^{\mathrm{a}}$ & $0 \pm 0^{\mathrm{a}}$ & $19.86 \pm 0.66^{\mathrm{ab}}$ & $59.2 \pm 1.71^{\mathrm{c}}$ & $45.85 \pm 15.87 \mathrm{bc}$ & $<0.05$ \\
\hline Isoquercitrin & $1541.5 \pm 783.89^{\mathrm{a}}$ & $0 \pm 0^{\mathrm{b}}$ & $80.5 \pm 4.03^{b}$ & $199.8 \pm 9.99 b c$ & $135.72 \pm 80.37 b c$ & $112.1 \pm 3.24 \mathrm{bc}$ & $1732.24 \pm 1629.62^{a}$ & $<0.05$ \\
\hline Luteolin & $86.43 \pm 43.6^{\mathrm{b}}$ & $129.96 \pm 4.9 \mathrm{bc}$ & $0 \pm 0^{\mathrm{a}}$ & $183.3 \pm 9.17^{c}$ & $114 \pm 1.81^{b c}$ & $151.8 \pm 4.38^{b c}$ & $115.68 \pm 39.38^{\mathrm{bc}}$ & $<0.001$ \\
\hline Luteolin-7-glucoside & $63.4 \pm 29.33^{a}$ & $127.98 \pm 35.1^{b}$ & $703.3 \pm 35.17^{b}$ & $33.8 \pm 1.69^{\mathrm{a}}$ & $453.58 \pm 215.59^{b}$ & $39.8 \pm 1.15^{a}$ & $3763.95 \pm 3487.18^{c}$ & $<0.05$ \\
\hline Luteolin-7-rutinoside & $40.07 \pm 20.03^{a}$ & $88.36 \pm 37.22^{a}$ & $0 \pm 0^{\mathrm{b}}$ & $37.8 \pm 1.89$ ab & $271.56 \pm 137.1^{c}$ & $0 \pm 0^{\mathrm{b}}$ & $83.5 \pm 57.68^{\mathrm{a}}$ & $<0.05$ \\
\hline Luteolin-3,7-diglucoside & $0 \pm 0$ & $0 \pm 0$ & $0 \pm 0$ & $0 \pm 0$ & $0 \pm 0$ & $0 \pm 0$ & $0 \pm 0$ & - \\
\hline Apigenin & $1.23 \pm 1.23$ & $0 \pm 0$ & $4 \pm 0.2$ & $3.3 \pm 0.17$ & $2.78 \pm 2.47$ & $0 \pm 0$ & $1.73 \pm 1.73$ & 0.45 \\
\hline Apigenin-7-glucoside & $0 \pm 0^{\mathrm{a}}$ & $0 \pm 0^{\mathrm{a}}$ & $216.5 \pm 10.83^{b}$ & $0 \pm 0^{\mathrm{a}}$ & $158.7 \pm 59.39^{b}$ & $0 \pm 0^{\mathrm{a}}$ & $0 \pm 0^{\mathrm{a}}$ & $<0.001$ \\
\hline Santin & $234.7 \pm 13.66^{\mathrm{ab}}$ & $784.02 \pm 287.25^{b}$ & $0 \pm 0^{\mathrm{a}}$ & $0 \pm 0^{\mathrm{a}}$ & $459.94 \pm 141.44 \mathrm{ab}$ & $0 \pm 0^{\mathrm{a}}$ & $267.03 \pm 107.43^{a b}$ & $<0.05$ \\
\hline
\end{tabular}

${ }^{1}$ Values (mean \pm SE) of the compounds marked by different letters $(\mathrm{a}, \mathrm{b})$ within the row were significantly differed at $p \leq 0.05$ among species according to the Duncan's Multiple Range test. 
Table 2. Mean quantities ( $\mu \mathrm{g} / \mathrm{g}$, DM) of phenolic compounds in inflorescences of Achillea spp. and their multivariate comparison among seven wild species.

\begin{tabular}{|c|c|c|c|c|c|c|c|c|}
\hline Compounds & A. cappadocica & A. setacea & A. aleppica & A. coarctata & $\begin{array}{l}\text { A.santolinoides } \\
\text { subsp. wilhelmsii }\end{array}$ & A. santolinoides & A. arabica & $p$ Value \\
\hline Neochlorogenic acid & ${ }^{1} 203.93 \pm 19.58$ & $289.58 \pm 37.88$ & $230.1 \pm 6.64$ & $152.1 \pm 4.39$ & $207.96 \pm 33.98$ & $228 \pm 6.58$ & $682.7 \pm 422.66$ & 0.41 \\
\hline Chlorogenic acid & $1049 \pm 176.38^{a b}$ & $3249.96 \pm 1109.51^{b}$ & $1405.8 \pm 40.58^{a b}$ & $672.4 \pm 19.41^{\mathrm{a}}$ & $839.7 \pm 270.28^{a}$ & $942.1 \pm 27.2^{\mathrm{ab}}$ & $2438.85 \pm 837.56^{\mathrm{ab}}$ & $<0.05$ \\
\hline 3.4-dicaffeoylquinic acid & $589.2 \pm 52.04^{\mathrm{ab}}$ & $1822.62 \pm 483.73^{b}$ & $456.7 \pm 13.18^{a}$ & $764.4 \pm 22.07^{\mathrm{ab}}$ & $299.58 \pm 56.53^{a}$ & $708.4 \pm 20.45^{\mathrm{sb}}$ & $839.8 \pm 639.54^{\mathrm{ab}}$ & $<0.05$ \\
\hline 3.5-dicaffeoylquinic acid & $2273.47 \pm 302.5^{\mathrm{ab}}$ & $5330.06 \pm 1314.69^{b}$ & $2102.7 \pm 60.7^{\mathrm{ab}}$ & $3097.6 \pm 89.42^{a b}$ & $1266.26 \pm 329.77^{a}$ & $1361.4 \pm 39.3^{\mathrm{a}}$ & $2125.35 \pm 1539.41^{\mathrm{ab}}$ & $<0.05$ \\
\hline 1.5-dicaffeoylquinic acid & $152.63 \pm 77.05^{\mathrm{a}}$ & $143.48 \pm 51.16^{\mathrm{a}}$ & $63.8 \pm 1.84^{\mathrm{a}}$ & $984.6 \pm 28.42^{b}$ & $28.32 \pm 19.59^{a}$ & $104.8 \pm 3.03^{a}$ & $105.8 \pm 90.06^{\mathrm{a}}$ & $<0.001$ \\
\hline 4.5-dicaffeoylquinic acid & $295.2 \pm 12.65^{\mathrm{ab}}$ & $456.88 \pm 95.26^{b}$ & $292.3 \pm 8.44^{\mathrm{ab}}$ & $3097.6 \pm 89.42^{c}$ & $207.94 \pm 41.49^{\mathrm{a}}$ & $209.7 \pm 6.05^{\mathrm{a}}$ & $242.2 \pm 66.74^{\mathrm{ab}}$ & $<0.001$ \\
\hline Quercitrin & $0 \pm 0^{a}$ & $0 \pm 0^{\mathrm{a}}$ & $0 \pm 0^{a}$ & $0 \pm 0^{\mathrm{a}}$ & $0 \pm 0^{\mathrm{a}}$ & $0 \pm 0^{\mathrm{a}}$ & $8487.21 \pm 3445.28^{b}$ & $<0.05$ \\
\hline Rutin & $155.93 \pm 49.75^{\mathrm{ab}}$ & $102.1 \pm 49.38^{a}$ & $0 \pm 0^{\mathrm{a}}$ & $93.6 \pm 2.7^{\mathrm{a}}$ & $10.1 \pm 10.1^{\mathrm{a}}$ & $63.1 \pm 1.82^{a}$ & $265.08 \pm 85.94^{b}$ & $<0.05$ \\
\hline Quercetin & $60.2 \pm 16.18^{a}$ & $35.58 \pm 5.07^{\mathrm{a}}$ & $40 \pm 1.15^{a}$ & $40.2 \pm 1.16^{\mathrm{a}}$ & $42.46 \pm 8.34^{\mathrm{a}}$ & $54.6 \pm 1.58^{a}$ & $203.7 \pm 134.08^{a}$ & $<0.05$ \\
\hline Isoquercitrin & $192.63 \pm 90.01^{\mathrm{ab}}$ & $513.58 \pm 174.94^{b}$ & $149.3 \pm 4.31^{\mathrm{ab}}$ & $24.9 \pm 0.72^{\mathrm{a}}$ & $54.14 \pm 22.35^{\mathrm{a}}$ & $51.6 \pm 1.49^{a}$ & $182.09 \pm 171.89 \mathrm{ab}$ & $<0.05$ \\
\hline Luteolin & $284.27 \pm 167.68^{a b}$ & $723.6 \pm 176.02^{b}$ & $0 \pm 0^{c}$ & $694.7 \pm 20.05^{b}$ & $245 \pm 34.84^{\mathrm{ab}}$ & $725.7 \pm 20.95^{b}$ & $560.05 \pm 360.27 \mathrm{ab}$ & $<0.05$ \\
\hline Luteolin-7-glucoside & $732.4 \pm 253.58^{a}$ & $1171.72 \pm 238.2^{\mathrm{a}}$ & $75.8 \pm 2.19^{a}$ & $181.2 \pm 5.23^{\mathrm{a}}$ & $520.06 \pm 154.57^{a}$ & $978.5 \pm 28.25^{\mathrm{a}}$ & $5646.13 \pm 3185.87^{b}$ & $<0.05$ \\
\hline Luteolin-7-rutinoside & $95.77 \pm 33.1^{\mathrm{a}}$ & $156.86 \pm 68.58^{a}$ & $37.8 \pm 1.09^{\mathrm{a}}$ & $0 \pm 0^{\mathrm{a}}$ & $170.38 \pm 46.78^{a}$ & $76.9 \pm 2.22^{\mathrm{a}}$ & $217.98 \pm 169.76^{\mathrm{a}}$ & $<0.05$ \\
\hline $\begin{array}{l}\text { Luteolin-3.7- } \\
\text { diglucoside }\end{array}$ & $0 \pm 0^{\mathrm{a}}$ & $531.26 \pm 260.77^{b}$ & $0 \pm 0^{\mathrm{a}}$ & $0 \pm 0^{\mathrm{a}}$ & $0 \pm 0^{\mathrm{a}}$ & $0 \pm 0^{\mathrm{a}}$ & $596.8 \pm 596.8^{b}$ & $<0.05$ \\
\hline Apigenin-7-glucoside & $138 \pm 97.09^{a}$ & $137.66 \pm 80.47^{\mathrm{a}}$ & $18.7 \pm 0.54^{b}$ & $0 \pm 0^{b}$ & $41.3 \pm 12.09^{b}$ & $99.3 \pm 2.87^{a b}$ & $13.28 \pm 13.28^{b}$ & $<0.05$ \\
\hline Santin & $229.07 \pm 10.36^{\mathrm{a}}$ & $548.8 \pm 190.9^{b}$ & $0 \pm 0^{c}$ & $0 \pm 0^{\mathrm{c}}$ & $228.32 \pm 16.21^{\mathrm{a}}$ & $0 \pm 0^{\mathrm{c}}$ & $321.7 \pm 90.89 \mathrm{ab}$ & $<0.05$ \\
\hline
\end{tabular}

${ }^{1}$ Values (mean \pm SE) of the compounds marked by different letters $(\mathrm{a}, \mathrm{b}, \mathrm{c})$ within the row were significantly differed at $p \leq 0.05$ among species according to the Duncan's Multiple Range test. 
Table 3. Mean quantities ( $\mu \mathrm{g} / \mathrm{g}, \mathrm{DM}$ ) of phenolic compounds in stems of Achillea spp. and their multivariate comparison among seven wild species.

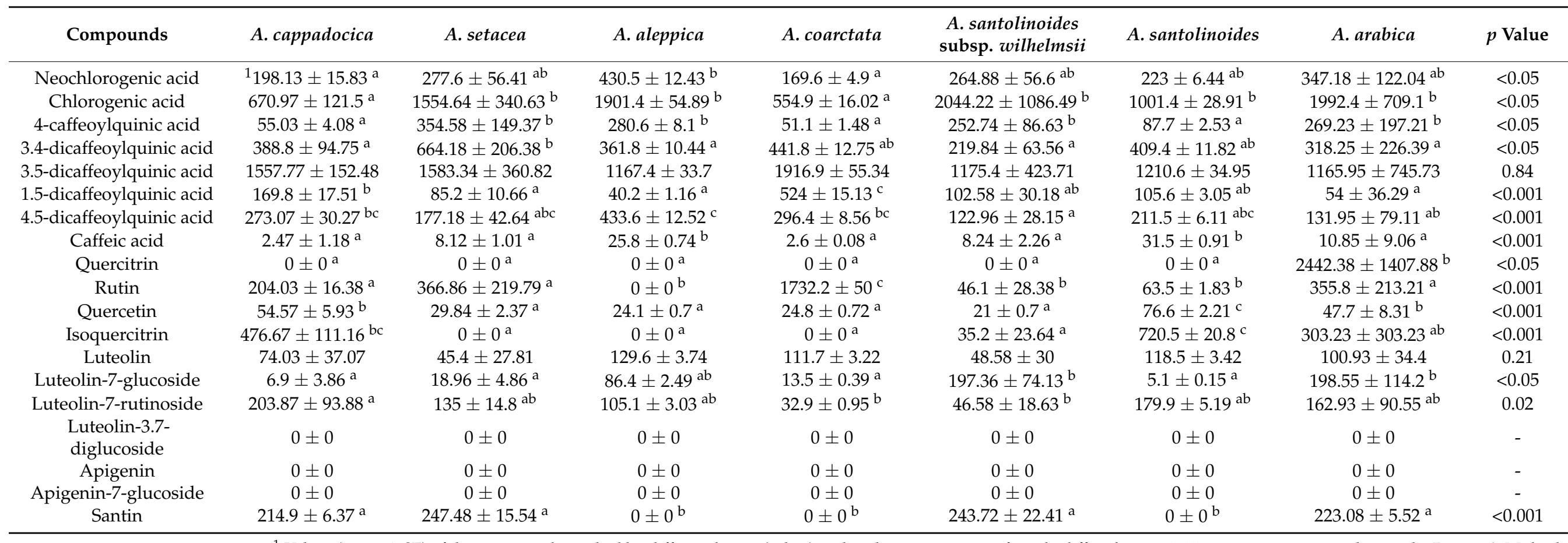

${ }^{1}$ Values (mean $\pm \mathrm{SE}$ ) of the compounds marked by different letters $(\mathrm{a}, \mathrm{b}, \mathrm{c})$ within the row were significantly differed at $p \leq 0.05$ among species according to the Duncan's Multiple Range test. 


\subsection{Antioxidant Activity of Leaves, Inflorescences, and Stems of Wild Achillea Species}

The results on antioxidant activity analysis revealed significant differences $(p \leq 0.05)$ among species and plant parts (Figure 1). The samples of A. arabica were elucidated with the highest TE values among all tested materials, $169.89 \pm 24.93,159.11 \pm 50.25$ and $84.39 \pm 15.50 \mu \mathrm{mol} / \mathrm{g}$, in leaves, inflorescences and stems, respectively. The leaves of all studied species were found to have priority over inflorescences and stems in terms of radical scavenging activity, with the exception for A. santolinoides, where no significant difference was found between the leaf and stem samples. The TE values of $A$. cappadocica and $A$. setacea leaf extracts were higher than $130 \mu \mathrm{mol} / \mathrm{g}$ and together with $A$. arabica showed the significantly highest $(p<0.05)$ antioxidant activity compared to the other species studied. Meanwhile, A. arabica was superior to other species in terms of the highest mean TE value in inflorescences. A. santolinoides, A. cappadocica, and A. setacea were superior in radical scavenging activity with the mean values of TE exeeding $79 \mu \mathrm{mol} / \mathrm{g}$. The leaves and inflorescences of $A$. aleppica, A. coarctata and A. santolinoides subsp. wilhelmsii were found to have comparable radical scavenging activity. No significant differences in antioxidant activity were found among the stems, except for A. arabica, whose stems differed in the higherst antioxidant activity $(84.39 \pm 15.50 \mu \mathrm{mol} / \mathrm{g}, p<0.05)$ compared to other species. The relationship between radical scavenging activity and population growing site in terms of its elevation was verified using Pearson correlational analysis. However, no significant correlations were found between the variables. Meanwhile, the radical scavenging activity of plant extracts showed a statistically significant correlation with the contents of some individual phenolics. There was a positive correlation between the contents of neochlorogenic acid $(r=0.545, p<0.0001)$, chlorogenic acid $(r=0.473$, $p<0.0001)$, 3,5-dacaffeoylquinic acid $(\mathrm{r}=0.310, p<0.0001)$, quercitrin $(\mathrm{r}=0.663, p<0.0001)$, quercetin $(\mathrm{r}=0.527, p<0.0001)$, and luteolin-7-glucoside $(\mathrm{r}=0.371, p<0.0001)$ and their antioxidant activities.

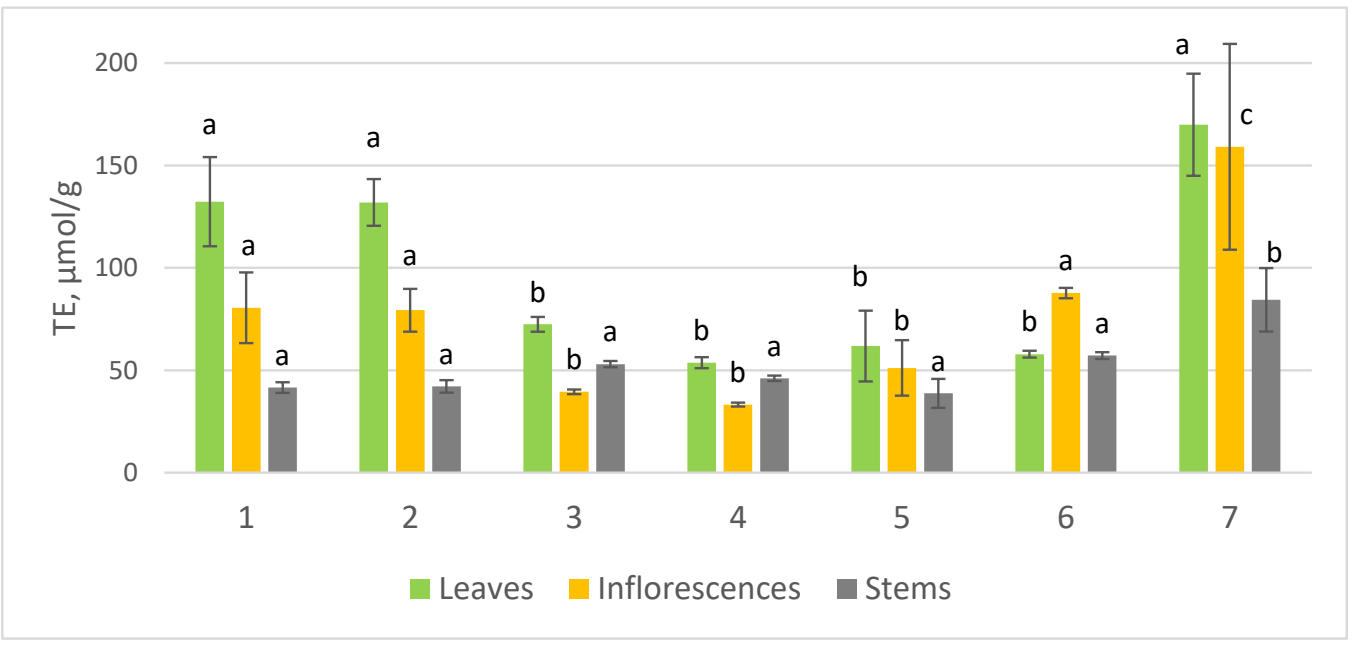

Figure 1. Variation of mean antioxidant activity $(\mathrm{TE}, \mu \mathrm{mol} / \mathrm{g})$ in plant parts of seven wild Achillea species: A. cappadocica (1); A. setacea (2); A. aleppica (3); A. coarctata (4); A. santolinoides subsp. wilhelmsii (5); A. santolinoides (6); A. arabica (7). The columns marked with the different letters (a, b, c) were significantly differed at $p \leq 0.05$ among species according to the Duncan's Multiple Range test.

Consequently, Achillea spp. exposed considerable antioxidant activity, which differed among species and plant parts in parallel to their individual phenolic compound contents. The high abundance of phenolics in A. arabica, A. setacea and A. cappadocica have induced a significant effect on the radical scavenging activity, with the greatest possible contribution of chlorogenic acid and quercetin derivatives. The leaves of all studied species were superior to inflorescences and stems in terms of radical scavenging activity. 


\subsection{Intra- and Interspecific Differences; Principal Component Analysis}

Principal component analysis (PCA) was performed to elucidate the intra- and interspecific differences in seven wild Achillea spp. according to the compound levels in their plant parts. Individual phenolic compounds were used as variables to create threedimensional PCA square matrix models to visualize the available intra-and interspecific patterns of Achillea spp. phenolic profiles in their plant parts.

The PCA1 score plot correlation matrix explained $65.52 \%$ of the total variance of the leaf data set model (Figure 2). PC1 accounted for $23.85 \%$ of the total data set and was positively correlated with mono-caffeoylquinic acids (neochlorogenic (0.969) and chlorogenic (0.819)) and quercitrin (0.868), and negatively with luteolin $(-0.544)$. PC2 explained $21.25 \%$ of the total variance and was highly positively correlated with 3,4-dicaffeoylquinic acid (0.859), 3,5dicaffeoylquinic acid (0.938), and santin (0.807). PC3 accounted for $20.39 \%$ of the total data set variance and was associated with rutin (0.861), isoquercitrin (0.709), luteolin-7-glucoside $(-0.628)$ and luteolin-7-rutinoside $(-0.511)$. The PCA1 score plot (Figure 2) showed the arrangement and grouping of populations of seven Achillea spp. tested. Populations of A. arabica (no 7) showed a distant position from other species, which can be explained by the high content of mono-caffeoylquinic acids and quercitrin in the leaves of this species. A. santolinoides subsp. wilhelmsii (no 5) populations clustered along negative PC2 and PC3 due to the high values of luteolin derivatives. Populations of $A$. cappadocica (no 1), A. setacea (no 2), and A. santolinoides (no 6) formed an overlapping group distinguished by a high quantitative similarity in the accumulation of 3,4- and 3,5-dicaffeoylquinic acids. The position of $A$. coarctata (no 4 ) can be explained by the contribution of rutin with a high positive PC3 loading.

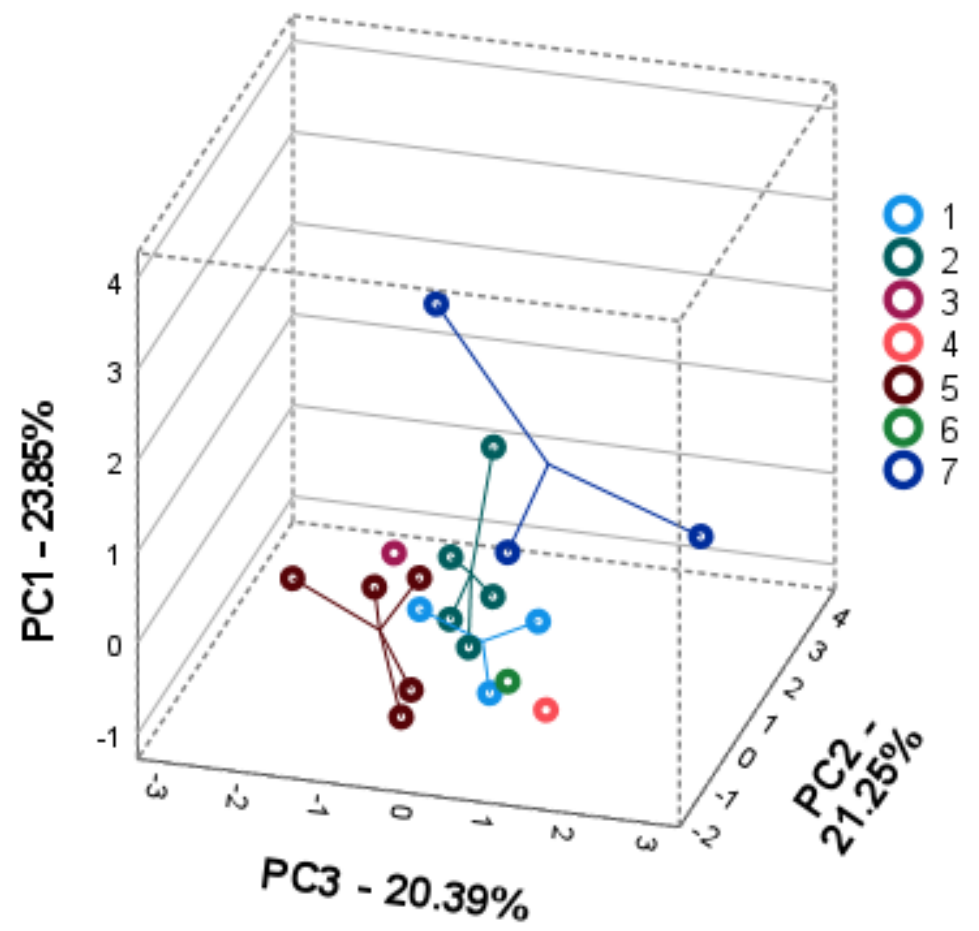

Figure 2. PCA1 score plots model representing the accumulation of phenolic compounds in leaves of seven Achillea species: A. cappadocica (1); A. setacea (2); A. aleppica (3); A. coarctata (4); A. santolinoides subsp. wilhelmsii (5); A. santolinoides (6); A. arabica (7).

The PCA2 score plot correlation matrix explained $84.81 \%$ of the total variance of the inflorescence data set model (Figure 3). PC1 accounted for $41.36 \%$ of the total variance and highly correlated with variables, namely rutin (0.613), isoquercitrin $(0.530)$, luteolin (0.902), luteolin-7-glucoside (0.648), luteolin-7-rutinoside (0.831), luteolin-3,7-diglucoside (0.922), and santin (0.556). PC2 explained $29.91 \%$ of the total variance and of the data 
set showing high correlation with neochlorogenic acid (0.982), quercitrin (0.957), rutin (0.680), and quercetin (0.976). PC3 accounted for $13.55 \%$ of the total variance and correlated with the variables, namely chlorogenic acid (0.907), 3,4-dicaffeoylqionic acid (0.911), 3,5dicaffeoylquinic acid (0.925), and isoquercitrin (0.614). The clustering of inflorescence differed from the leaf grouping pattern (Figure 3 ). The inflorescences of $A$. cappadocica (no 1), A. coarctata (no 4), A. santolinoides subsp. wilhelmsii (no 5), and A. santolinoides (no 6) were clustered in a close group along the negative PC2 and PC3 with high contributions of chlorogenic acid, 3,4-and 3,5-dicaffeoylquinic acids, and isoquercitrin. A. aleppica (no 3) positioned apart from the abovementioned cluster of species, at lower PC1 position with the contribution with the contribution of the lowest flavonoid contents. A. setacea (no 2) and $A$. arabica) (no 7) populations were highly scattered on the PCs score plots displaying a higher variation of bioactive compounds than other species.

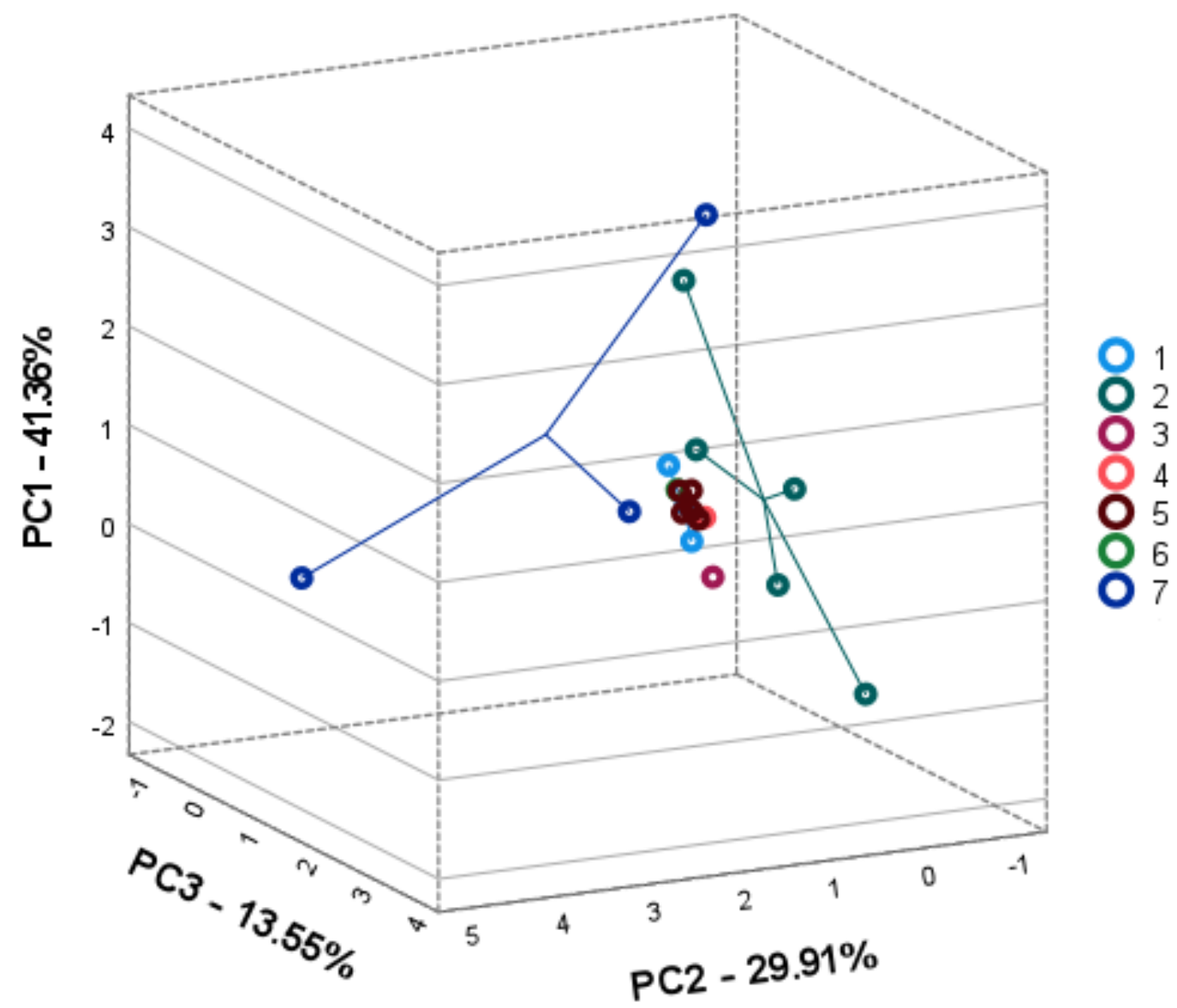

Figure 3. PCA2 score plots model representing the accumulation of phenolic compounds in inflorescences of seven Achillea species: A. cappadocica (1); A. setacea (2); A. aleppica (3); A. coarctata (4); A. santolinoides subsp. wilhelmsii (5); A. santolinoides (6); A. arabica (7).

The PCA3 score plot correlation matrix explained $58.53 \%$ of the total variance of the stem data set model (Figure 4). PC1 accounted for $25.54 \%$ or the total variance and high correlated with the loadings of dicaffeoylquinic acids, namely 3,4-dicaffeoylquinic (0.655), 3,5-dicaffeoylquinic (0.840), and 4,5-dicaffeoylquinic (0.743) acids. PC2 covered 20.13\% of the total variance and correlated with neochlorogenic acid (0.658), chlorogenic acid (0.799), and luteolin-7-glucoside (0.793) and negatively with quercetin $(-0.671)$. PC3 explained $12.83 \%$ of the variance and correlated with santin $(0.820)$ and negatively with rutin $(-0.541)$ and luteolin $(-0.500)$. The stems of Achillea spp. were clustered into four groups on the score plot. The first group on the left, negative PC2 and PC3, coupled A. cappadocica (no 1) and $A$. santolionides (no 6) populations with the lowest amounts of chlorogenic acid, luteolin- 
7-glucoside. The second group showed a similarity between the stems of A. aleppica (no 3) and $A$. coarctata (no 4). The third group, consisting of $A$. setacea (no 2 ) and $A$. arabica (no 7) populations, showed a high similarity in the amounts of caffeoylquinic acids in their stems. The arrangement of $A$. santolinoides subsp. wilhelmsii (no 5) populations coincided with impact of chlorogenic acid and luteolin-7-glucoside.

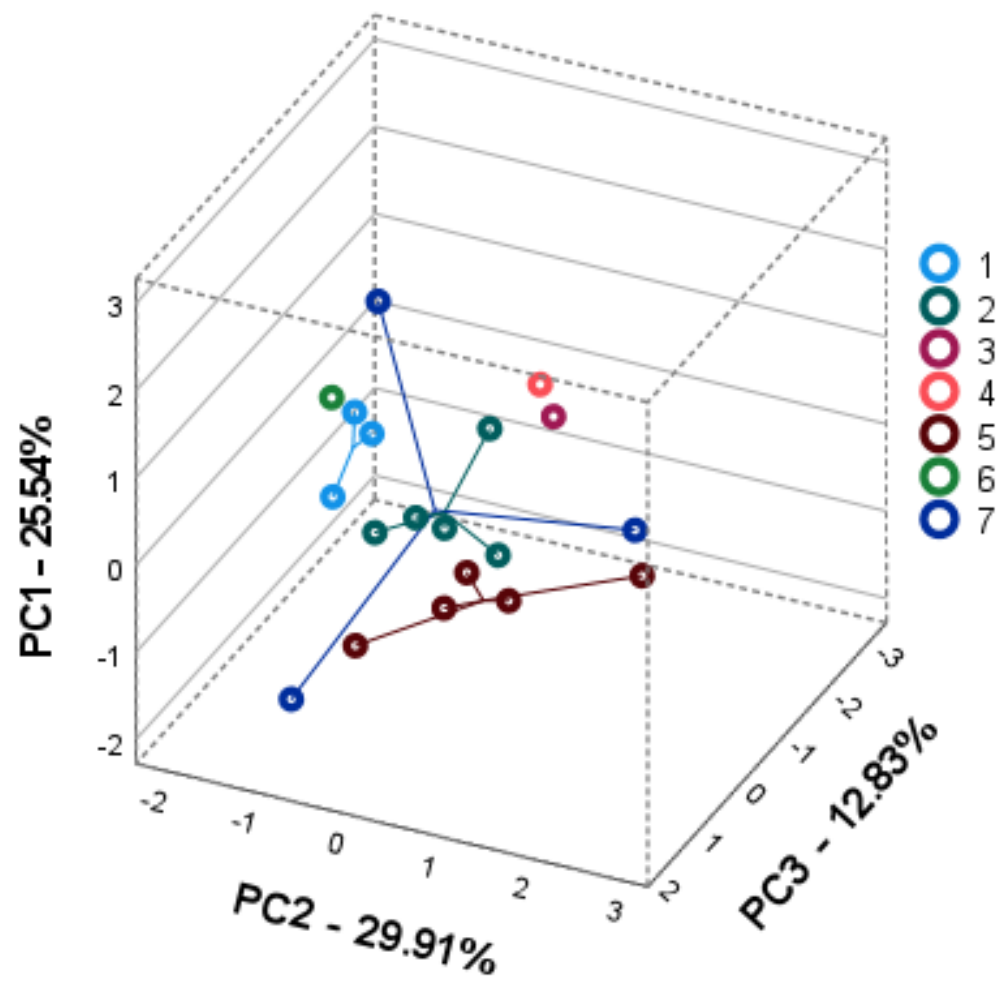

Figure 4. PCA2 score plots model representing the accumulation of phenolic compounds in stems of seven Achillea species: A. cappadocica (1); A. setacea (2); A. aleppica (3); A. coarctata (4); A. santolinoides subsp. wilhelmsii (5); A. santolinoides (6); A. arabica (7).

Consequently, the multivariate phytochemical patterns complemented the intra- and interspecific diversity of seven Achillea spp. according to the contribution of individual caffeoylquinic acids and flavonoids for their clustering in PCA models. Among the species studied, A. arabica and A. setacea displayed the highest intraspecific chemical diversity. Distant position of $A$. arabica was determined by the highest accumulation of mono-caffeoylquinic acids, quercitrin and luteolin-7-glucoside in all plant parts compared to the other species. The arrangement of $A$. setacea populations was confirmed by the high contribution of chlorogenic acid and 3,4- and 3,5-dicaffeoylquinic acids. Achillea cappadocica, A. coarctata, and $A$. santolinoides showed significant similarity in dicaffeoylquinic acid accumulation in leaves and inflorescences. Achillea santolinoides subsp. wilhelmsii and A. alepica were distinguished from the other species by the lowest levels of caffeoylquinic acids and flavonoids, respectively.

\section{Discussion}

Achillea species, compared to many other plant species, are particularly rich in a broad variety of specialized metabolites. The diversity of Achillea spp. was assessed on the specific profiles of triterpenes, sterols, polyacetylenes, flavonoids, and phenolic acids, which depend on species-specific characteristics, genotype, stage of ontogenesis and vegetation, as well as climatic and edaphic factors [31,32]. Most chemical studies to date have been performed on $A$. millefolium. However, there are several reports on the composition of phenolic compounds of the species analysed in this study including A. arabica $[14,30,33,34]$, A. santolinoides subsp. wilhelmsii, A. setacea [30], and A. coarctata [28,33]. Gevrenova et al. [20] 
tentatively identified various metabolites in the areal parts and roots of A. aleppica subsp. zederbaueri (Hayek) Hub.-Mor. and A santolinoides subsp. wilhelmsii areal parts and roots, including 14 hydroxybenzoic and hydroxycinnamic acids, along with 24 glycosyl flavonoids and 12 flavonoid aglycons.

Among the specialized metabolites identified in Achillea spp., phenolic compounds, including caffeoylquinic acids and flavonoids, were considered as a particularly important group because they contribute to the major multifunctional biological activity that may be linked to their antioxidant potential [35]. Caffeoylquinic acids, esters of caffeic acid with quinic acid, have many benefits for therapeutic applications, as were reported about their antioxidant, antibacterial, antiviral, neuroprotective, anticancer, anti-Alzheimer, and anti-diabetes properties [36]. Caffeoylquinic acids, especially 4,5-dicaffeoylquinic acid, have great applications in cosmetic skin whitening products due to their potential for tyrosinase inhibition and tyrosinase transcription gene downregulation [34,37]. It was considered that the biological activities of dicaffeoylquinic acids are attributed to the relative positions of caffeoyl moieties and affected by the structural characteristics of the cyclohexane skeleton [32]. The 3,4- and 4,5-dicaffeoylquinic acids with two adjacent caffeoyl moieties potentially possessed a higher antioxidant capacity than three non-adjacent dicaffeoylquinic acids (1,3-, 1,5- and 3,5-dicaffeoylquinic acids). On the other hand, dicaffeoylquinic acids with non-adjacent caffeoyl moieties exhibited a higher cytoprotective effect than adjacent dicaffeoylquinic acids [38]. Caffeoylquinic acids are photosensitive and chemically unstable, although monocaffeoylquinic acids are far more stable than dicaffeoylquinic acids. Similar to our identification, previous reports indicated that chlorogenic acid was most frequently quantified as the predominant caffeoylquinic acid in $A$. arabica, A. setacea, A. santolinoides subsp. wilhelmsii [14,20,30], A. coarctata [28,30], and A. aleppica subsp. zederbaueri [20] profiles. In addition, 4,5-dicaffeoylquinic acid, 3,5-dicaffeoylquinic acid, and 1,3-dicaffeoylquinic acid were reported to be predominant in A. arabica, A. aleppica subsp. zederbaueri, and $A$. santolinoides subsp. wilhelmsii, respectively $[20,34]$. In our study, 3,4-dicaffeoylquinic, 3,5-dicaffeoylquinic and 4,5-dicaffeoylquinic acids predominated in $A$. setacea and $A$. coarctata extracts, and apparently resulted in the highest antioxidant activity of these species. No 1,3-dicaffeoylquinic acid was detected in the species tested.

Overall, Achillea spp. accumulate higher amounts of caffeoylquinic acids compared to flavonoids $[14,28,33,37]$. Our results confirmed this trend, as a higher proportion of total caffeoylquinic acids was detected in the inflorescences, leaves, and stems of all studied species except for $A$. arabica inflorescences. Differently than other species, $A$. arabica accumulated higher amounts of flavonoids than caffeoylquinic acids. A. arabica exposed an exceptional quantitative profile of flavonoids with the greatest levels of quercetin and luteolin derivatives and flavone santin. Similar to our identification, previous studies reported the higher levels of phenolic compounds in A. arabica compared to other Achillea spp. [29,34,39-41]. Furthermore, A. arabica extracts revealed considerable antioxidant activity, suggesting a great contribution of flavonoids to radical scavenging capacity. The radical scavenging potential of flavonoids is determined by the structure of the molecule in which the position and degree of hydroxylation are essential for their antioxidant activity. In this respect, quercetin and its glycosides combine all the structural characteristics of high radical scavenging potential [42]. In addition, the antiradical properties of the extracts might be due to the synergistic action between constituents. A greater synergistic effect was demonstrated for a combination of chlorogenic acid and isoquercitrin in Sorbus domestica leaf extracts [43]. This type of interaction possible influenced the antioxidant activity of A. arabica extracts. The notable antiradical capacity was also confirmed in $A$. cappadocica extracts, which was associated with high levels of flavonoids and chlorogenic acid. To the best of our knowledge, the profile of $A$. cappadocica, A. aleppica and A. santolinoides phenolic compounds and the assessment of antioxidant activity were presented for the first time.

Our results are consistent with previous studies that confirmed the presence of rutin, quercetin, luteolin and apigenin in A. arabica, A. coarctata, A. setacea, and $A$. santolinoides subsp. wilhelmsii $[28,30]$ raw materials. However, these studies did not present the quantifi- 
cation of flavonoid glycosides in corresponding species, except for isoquercitrin and rutin in $A$. coarctata [28]. In agreement with our results, rutin was identified as the predominant flavonoid in $A$. coarctata. Meanwhile, in another study of $A$. coarctata, rutin was not found at all, although in all cases plant material was collected from Turkey [33]. As far as we know, in our study, the methylated flavone santin was for the first time quantified in the leaves, inflorescences and stems of $A$. cappadocica, A. setacea, A. santolinoides subsp. wilhelmsii, and A. arabica. Gevrenova et al. [20] reported the identification of santin in A. santolinoides subsp. wilhelmsii and A. aleppica subsp. zederbaueri areal parts from Bulgaria. However, we did not detect santin in A. aleppica originating from Turkey. Small amounts of santin was reported in A. biebersteinii (A. arabica) from Egypt [44]. Santin belongs to lipophilic surface flavonoids with notable antifungal [45] and anti-inflammatory effects [46].

In most previous reports the authors did not specify plant organs, so these data cannot be directly compared with the results presented. Moreover, differences in the comparisons of phenolic compounds composition may be due to inaccuracies in the taxonomic identification of species, harvesting time, methods of extraction, and chemical analysis. According to Zidorn [47] correct species identification is a crucial condition for meaningful phytochemical studies, as well as in comparing data performed by different researchers allegedly working on the same species. Consequently, the comparison of the chemical data has many inconsistencies, but it helps to form an overall picture of the chemical potential of the relevant species' raw materials.

The chemical diversity of specialized metabolites in vascular plants is a common occurrence affected by different exogenous and endogenous factors that lead to creating new metabolome patterns and formation of intraspecific differences [48]. In this regard, environmental factors, including latitudinal and longitudinal gradients, have been considered to be important in explaining the intraspecific differences of specialized metabolites that may reflect adaptations of plant to local conditions [49]. However, the study of the phenolic profiles of the species over a regional or gradient range will complement the knowledge on the distribution of specialized metabolites in Achillea spp. and enrich the information on their biochemical resources. The intraspecific diversity of specialized metabolites is only partly related to the environment. The response of organisms to changes in the abiotic or biotic environment is often genetically controlled [50]. Recently, a new term, chemophenetics, has been proposed to describe an array of specialized metabolites in a given taxon [51]. Chemophenetic information, together with other recognized approaches, contributes to the phenetic description of taxa. The variable phenolic profile patterns across species provide information on the array of distinctive compounds and are an important tool in chemophenetic studies of heterogeneous Achillea spp. An example would be the flavonoid santin, which, according to Williams et al. [46], is more frequently occuring in the genus Achillea than in other genera of Asteraceae. Santin was reported in 35\% species of section Filipendulinae and in some taxa of section Nobilis, providing its chemotaxonomic significance at the section level. In this study, santin was quantified in species of section Achillea (A. arabica, A. cappadocica, and A. setacea) and section Santolinoideae (A. santolinoides subsp. wilhelmsii) [52]. Thus, the new data will complement the information on the prevalence of santin in other sections of the genus Achillea. In this context, the use of chemotaxonomic knowledge is appropriate for the selection of wild plant material of relevant taxa that is known to produce desired compounds associated with a particular biological activity or therapeutic effect.

\section{Materials and Methods}

\subsection{Plant Material Collection and Identification}

Plant material of seven species, Achillea arabica, A. aleppica, A. cappadocica, A. coarctata, A. santalinoides, A. santolinoides subsp. wilhelmsii, and $A$. setacea, representing 30 randomly selected single shoots per population, was collected at full flowering phase during a short period, from 24 to 30 of June 2018. Plants were harvested between $11 \mathrm{~h}$ to $13 \mathrm{~h}$ to avoid differences in daily variation of metabolism. The plants were collected from 
19 wild populations in the provinces of Gaziantep and Kahramanmaras in the region of Southeastern Anatolia, the provinces of Nevşehir and Niğde in Central Anatolia, and the provinces of Samsun, Amasya and Çorum in the Black Sea region (Figure 5). Sampling sites were geocoded using a Garmin etrex-10 Global Positioning System receiver and exported to map processing software.

Table 4. Voucher numbers, geographical data of collection sites and habitats of the studied Achillea species.

\begin{tabular}{|c|c|c|c|c|c|c|c|}
\hline Species & Population & $\begin{array}{l}\text { Voucher } \\
\text { Number }\end{array}$ & $\begin{array}{c}\text { Province, } \\
\text { Geographical } \\
\text { Region }\end{array}$ & $\begin{array}{l}\text { Latitude } \\
\left({ }^{\circ} \mathbf{N}\right)\end{array}$ & $\begin{array}{l}\text { Longitude } \\
\left({ }^{\circ} \mathrm{E}\right)\end{array}$ & $\begin{array}{l}\text { Elevation } \\
\text { (m a.s.l.) }\end{array}$ & Habitat \\
\hline \multirow{3}{*}{ A. cappadocica } & 1 & BMYO \#AC1 & $\begin{array}{l}\text { Niğde, Southern } \\
\text { Anatolia }\end{array}$ & 37.54 & 34.54 & 2057 & Conifer woodland \\
\hline & 2 & BMYO \#AC2 & $\begin{array}{l}\text { Nevşehir, Central } \\
\text { Anatolia }\end{array}$ & 38.28 & 34.40 & 1596 & Highland meadow \\
\hline & 3 & BMYO \#AC3 & $\begin{array}{l}\text { Nevşehir, Central } \\
\text { Anatolia }\end{array}$ & 38.39 & 34.29 & 937 & Highland meadow \\
\hline \multirow{5}{*}{ A. setacea } & 1 & BMYO \#AS1 & Çorum, Black Sea & 40.53 & 35.13 & 1012 & $\begin{array}{l}\text { Barren mountain } \\
\text { slope }\end{array}$ \\
\hline & 2 & BMYO \#AS2 & Amasya, Black Sea & 40.47 & 35.25 & 914 & $\begin{array}{l}\text { Barren mountain } \\
\text { slope }\end{array}$ \\
\hline & 3 & BMYO \#AS3 & Çorum, Black Sea & 40.56 & 35.39 & 1197 & $\begin{array}{l}\text { Barren mountain } \\
\text { slope }\end{array}$ \\
\hline & 4 & BMYO \#AS4 & Amasya, Black Sea & 41.04 & 42.13 & 1117 & Stony roadside \\
\hline & 5 & BMYO \#AS5 & Samsun, Black Sea & 41.09 & 35.11 & 664 & Stony roadside \\
\hline A. aleppica & 1 & BMYO \#Aa1 & $\begin{array}{c}\text { Gaziantep, } \\
\text { Southeastern } \\
\text { Anatolia }\end{array}$ & 37.09 & 37.24 & 668 & $\begin{array}{l}\text { Calcareous } \\
\text { mountainside }\end{array}$ \\
\hline A. coarctata & 1 & BMYO\#Аа2 & $\begin{array}{c}\text { Gaziantep, } \\
\text { Southeastern } \\
\text { Anatolia }\end{array}$ & 37.16 & 37.46 & 446 & Stony roadside \\
\hline \multirow{5}{*}{$\begin{array}{l}\text { A. santolinoides } \\
\text { subsp. wilhelmsii }\end{array}$} & 1 & BMYO \#AW1 & $\begin{array}{c}\text { Gaziantep, } \\
\text { Southeastern } \\
\text { Anatolia }\end{array}$ & 36.52 & 36.59 & 1054 & $\begin{array}{l}\text { High altitude stony } \\
\text { land }\end{array}$ \\
\hline & 2 & BMYO \#AW2 & $\begin{array}{l}\text { Niğde, Central } \\
\text { Anatolia }\end{array}$ & 38.21 & 34.22 & 1384 & $\begin{array}{c}\text { Stony calcareous } \\
\text { areas }\end{array}$ \\
\hline & 3 & BMYO \#AW3 & $\begin{array}{l}\text { Niğde, Central } \\
\text { Anatolia }\end{array}$ & 38.25 & 34.51 & 1726 & $\begin{array}{c}\text { Stony calcareous } \\
\text { area }\end{array}$ \\
\hline & 4 & BMYO \#AW4 & $\begin{array}{l}\text { Niğde, Central } \\
\text { Anatolia }\end{array}$ & 38.27 & $34^{\circ} .59$ & 1661 & $\begin{array}{c}\text { Calcareous stony } \\
\text { areas }\end{array}$ \\
\hline & 5 & BMYO \#AW5 & $\begin{array}{l}\text { Nevşehir, Central } \\
\text { Anatolia }\end{array}$ & 39.38 & 35.54 & 1139 & $\begin{array}{c}\text { Calcareous stony } \\
\text { area }\end{array}$ \\
\hline A. santolinoides & 1 & BMYO \#Aа3 & $\begin{array}{c}\text { Gaziantep, } \\
\text { Southeastern } \\
\text { Anatolia }\end{array}$ & 37.20 & 37.03 & 520 & Stony roadside \\
\hline \multirow{3}{*}{ A. arabica } & 1 & $\begin{array}{l}\text { BMYO* } \\
\text { \#AA54 }\end{array}$ & $\begin{array}{c}\text { Kahramanmaraş, } \\
\text { Southeastern } \\
\text { Anatolia }\end{array}$ & 36.58 & 37.24 & 975 & Conifer woodland \\
\hline & 2 & BMYO \# AA55 & $\begin{array}{c}\text { Gaziantep, } \\
\text { South-eastern } \\
\text { Anatolia }\end{array}$ & 37.06 & 37.38 & 682 & Conifer woodland \\
\hline & 3 & BMYO \# AA56 & $\begin{array}{c}\text { Gaziantep, } \\
\text { Southeastern } \\
\text { Anatolia }\end{array}$ & 37.01 & 37.06 & 1276 & Conifer woodland \\
\hline
\end{tabular}

* Bafra Meslek Yüksek Okulu (Vocational High School of Bafra). 


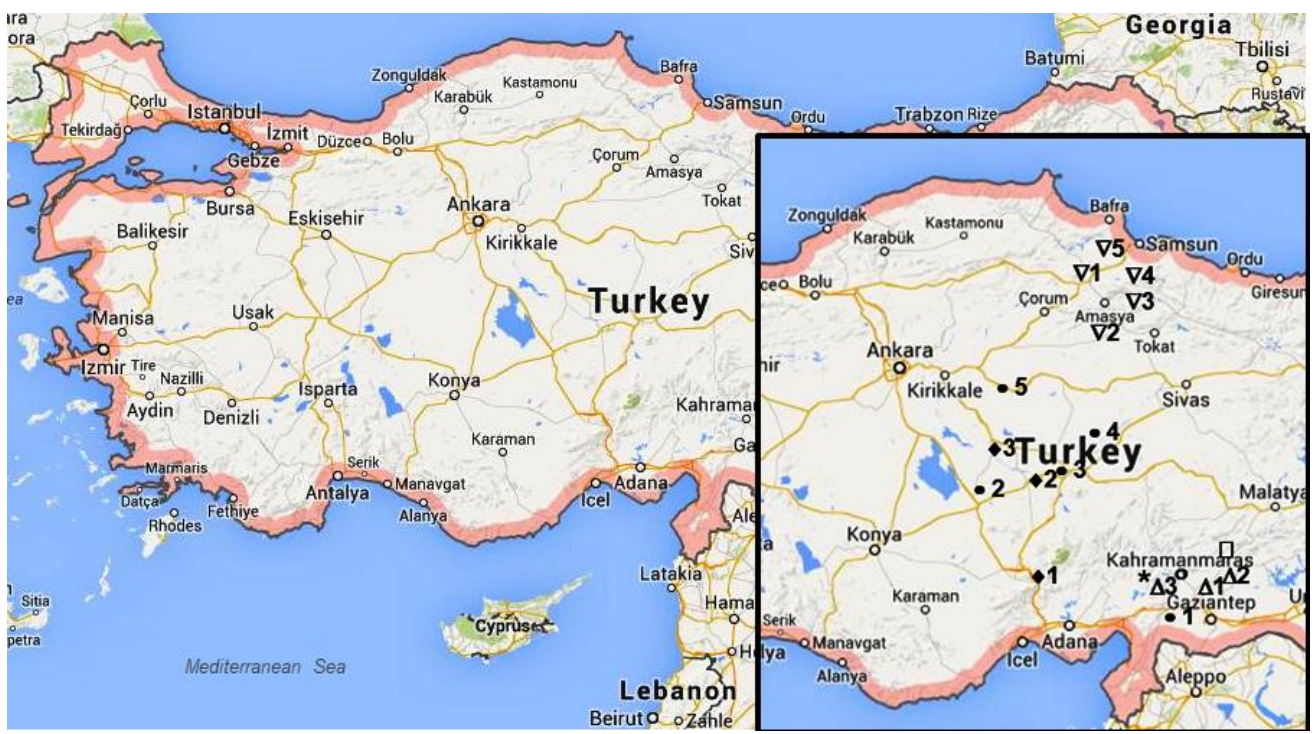

Figure 5. The collection sites of Achillea arabica ( $\Delta$ ), Achillea aleppica (o), Achillea coarctata ( $\square$ ), Achillea santalinoides $(*)$, Achillea cappadocica $(\diamond)$, Achillea santolinoides subsp. wilhelmsii $(\bullet)$, and Achillea setacea $(\nabla)$. The number of populations corresponded to No. listed in Table 4.

The plant material was dissected into inflorescences, leaves and stems and separately dried at room temperature. The air-dried plant material was mechanically ground to obtain a homogeneous drug powder and stored at $4{ }^{\circ} \mathrm{C}$ until extraction.

Botanical identification of species was performed on morphological characters according to Güner et al. [3], and valid plant names were verified against The Plant List [3,15]. The voucher specimens were deposited in the herbarium of Ondokuz Mayis University, Vocational High School of Bafra (Table 4).

\subsection{Chemicals}

The following solvents were used in the present study: $99.9 \%$ acetonitrile, $99.9 \%$ methanol, obtained from Sigma-Aldrich (Steinheim, Germany) and 99.8\% trifluoroacetic acid supplied from Merck (Darmstadt, Germany). The water was purified using a Millipore Milli-Q apparatus. Analytical and HPLC grade substances: potassium persulphate, 2,2'-azino-bis(3-ethylbenzothiazoline-6-sulfonic acid) diammonium salt (ABTS), caffeic, neochlorogenic, chlorogenic, 4-caffeoylquinic, 3,4-dicaffeoylquinic, 3,5-dicaffeoylquinic, 1,5dicaffeoylquinic, and 4,5-dicaffeoylquinic acids, rutin, quercitrin, quercetin, isoquercitrin, luteolin-7-glucoside, luteolin-7-rutinoside, luteolin-3,7-diglucoside, apigenin-7-glucoside, and santin were obtained from Sigma-Aldrich; luteolin from Roth GmbH (Karlsruhe, Germany); trolox and apigenin from Fluka Chemika (Buchs, Switzerland).

\subsection{Sample Preparation}

A precise weight $(0.1 \mathrm{~g})$ of each sample plant powder was extracted in $10 \mathrm{~mL}$ of $70 \%$ methanol in an ultrasonic bath (WiseClean). The extracts were filtered through $0.22 \mu \mathrm{m}$ syringe filters (Carl RothGmbH \& Co. KG, Karlsruhe, Germany) and stored at $4{ }^{\circ} \mathrm{C}$ until analysis.

\subsection{Antioxidant Activity Assay}

The radical scavenging ABTS assay was performed as described by Re et al. [53] with modifications as described by Raudone et al. [54].

\subsection{HPLC Analysis}

The chemical composition of phenolic composition was performed by using Waters e2695 Alliance HPLC system coupled with a 2996 PDA detector (Waters, Milford, MA, USA) and the method described by Vilkickyte et al. [55]. Phenolic compounds were separated 
on an ACE Super C18 (250 mm $\times 4.6 \mathrm{~mm}, 3 \mu \mathrm{m})$ column (ACT, Aberdeen, UK), operated at a constant temperature of $35^{\circ} \mathrm{C}$. The gradient elution mode consisting of $0.1 \%(v / v)$ trifluoroacetic acid in pure water $(\mathrm{A})$ and acetonitrile $(\mathrm{B})$ was as follows: $0 \mathrm{~min}, 10 \% \mathrm{~B}$; 0-40 $\mathrm{min}, 30 \% \mathrm{~B} ; 40-60 \mathrm{~min}, 70 \% \mathrm{~B} ; 60-64 \mathrm{~min}, 90 \% \mathrm{~B} ; 64-70 \mathrm{~min}, 10 \%$. The flow rate was $0.5 \mathrm{~mL} / \mathrm{min}$, and the injection volume was $10 \mu \mathrm{L}$. The analytical HPLC-PDA method was validated according to the ICH Q2 (R1) guidelines [56]. Identification was performed by scanning in a range of $200-400 \mathrm{~nm}$ wavelengths by comparing spectral data and retention times to those of standard compounds. Representative chromatograms of Achillea spp. raw materials are given in Supplementary Figure S1. For quantification, 5-7 points linear calibration curves $(r>0.999)$ were constructed by plotting the response of each analyte, considered by target concentrations (in the range of 1.6-200.0 $\mu \mathrm{g} / \mathrm{mL}$ ). Obtained limits of detection (LOD) and quantification (LOQ), determined using the signal-to-noise ratio method, are presented in Supplementary Table S1. Precision values (repeatability of replicates on the same day and intermediate precision on three consecutive days), expressed as percentage relative standard deviations (\% RSD) of peak areas did not exceed the $2 \%$ threshold. Percent recoveries of studied phenolic compounds were in the acceptable range of $90-110 \%$ for our studied concentration levels, showing the trueness of the method.

\subsection{Statistical Analysis}

All investigations were performed in triplicate and expressed as mean \pm standard error. An ANOVA, followed by post hoc Duncan 's Multiple Range test, was completed to identify significant differences at $p<0.05$. Pearson's correlation was analyzed, and $p$-value obtained by checking hypothesis on nonlinear regression was used. Principal component analysis (PCA) was performed considering factors with eigenvalues higher than one. Kaiser-Meyer-Olkin measure of sampling adequacy and Bartlett's Test were used to test the suitability of the model. The data analysis was performed using SPSS 20 software package.

\section{Conclusions}

The study for the first time reported the fingerprinting of phenolic compounds of areal plant parts of seven Achillea spp. together with pronounced antiradical activity of their extracts. Profiles of Achillea spp. and plant parts differed in the prevalence of individual caffeoylquinic acids and flavonoids. Among the species studied, A. arabica and A. setacea populations were displayed by the highest intraspecific chemical diversity, suggesting a greater selection of chemical phenotypes. Achillea setacea excelled with the highest total caffeoylquinic acid content, and A. arabica accumulated the highest amounts of flavonoids among the species studied. Achillea santolinoides subsp. wilhelmsii profiles coincided with the lowest content of caffeoylquinic acids, while $A$. alepica with flavonoids. Furthermore, phenolic profile patterns of seven Achillea spp. provide information on species-specific individual phenolic compounds that are considered as an important tool in chemophenetic studies of heterogeneous Achillea spp. and may be relevant for the selection of target raw materials. The functional benefit of plants extracts was confirmed by their antioxidant activity, which was most pronounced in A. arabica, A. setacea, and A. cappadocica, and which can be considered as potential sources of antioxidants for further applications.

The findings suggest that the high diversity of chemical profiles of Achillea spp. leads to a high potential to find new sources of multifunctional phenolic compounds. To further assess and compile the potential of the underutilized Achillea spp., it is important to take a broad interdisciplinary approach covering not only phytochemistry, but also ethnopharmacological knowledge, chemotaxonomy, botany, and relevant pharmacological and biological research.

Supplementary Materials: The following supporting information can be downloaded at: https: / www. mdpi.com/article/10.3390/plants11030447/s1, Figure S1: Representative HPLC-PDA chromatograms $(\lambda=330 \mathrm{~nm}$ ) of Achillea spp. (A. setacea) (A) leaves, (B) stems, and (C) inflorescences, showing separation of: 1-neochlorogenic acid, 2-chlorogenic acid, 3-4-caffeoylquinic acid, 4-luteolin-3.7-diglucoside, 
5-caffeic acid, 6-luteolin-7-rutinoside, 7-rutin, 8-luteolin-7-glucoside, 9-isoquercitrin, 10-4.5dicaffeoylquinic acid, 11-apigenin-7-glucoside, 12-1.5-dicaffeoylquinic acid, 13-3.5-dicaffeoylquinic acid, 14-3.4-dicaffeoylquinic acid, 15-luteolin, 16 -quercetin, 17-apigenin, 18-santin.; Table S1: HPLC-PDA method identification and quantification parameters.

Author Contributions: Conceptualization, J.R. and C.C.; methodology, G.V.; formal analysis, L.R.; investigation, G.V. and M.M.; resources, F.S., F.Y. and L.I.; data curation, L.R.; writing-original draft preparation, L.R. and J.R.; writing - review and editing, J.R. and L.R.; visualization, L.R. and J.R.; supervision, J.R. All authors have read and agreed to the published version of the manuscript.

Funding: This research received no external funding.

Institutional Review Board Statement: Not applicable.

Informed Consent Statement: Not applicable.

Data Availability Statement: Data is contained within the article or supplementary material.

Conflicts of Interest: The authors declare no conflict of interest.

\section{References}

1. Leaman, D.J. Sustainable wild collection of medicinal and aromatic plants Development of an international standard. In Medicinal and Aromatic Plants; Bogers, R.J., Ed.; Springer: Berlin/Heidelberg, Germany, 2006; pp. 97-107.

2. Ehrendorfer, F.; Guo, Y.-P. Multidisciplinary studies on Achillea sensu lato (Compositae-Anthemideae): New data on systematics and phylogeography. Willdenowia 2006, 36, 69-87. [CrossRef]

3. Güner, A.; Aslan, S.; Ekim, T.; Vural, M.; Babaç, M. Turkey Plant List (tracheophyta); Türkiye Bitk: Istanbul, Turkey, 2012.

4. Applequist, W.L.; Moerman, D.E. Yarrow (Achillea millefolium L.): A Neglected Panacea? A Review of Ethnobotany, Bioactivity, and Biomedical Research1. Econ. Bot. 2011, 65, 209-225. [CrossRef]

5. Honda, G.; Yeşilada, E.; Tabata, M.; Sezik, E.; Fujita, T.; Takeda, Y.; Takaishi, Y.; Tanaka, T. Traditional medicine in Turkey VI. Folk medicine in West Anatolia: Afyon, Kütahya, Denizli, Muğla, Aydin provinces. J. Ethnopharmacol. 1996, 53, 75-87. [CrossRef] [PubMed]

6. European Pharmacopoeia 10.3. 2021. Available online: https://pheur.edqm.eu/subhome/10-3 (accessed on 13 January 2022).

7. Zsuzsanna, R.; Biró-Sándor, Z. Assessment Report on Achillea millefolium L.; Committee on Herbal Medicinal Products (HMPC): Amsterdam, The Netherlands, 2009.

8. Ali, S.I.; Gopalakrishnan, B.; Venkatesalu, V. Pharmacognosy, Phytochemistry and Pharmacological Properties of Achillea millefolium L.: A Review. Phytother. Res. 2017, 31, 1140-1161. [CrossRef] [PubMed]

9. Valant-Vetschera, K.M. On the identity of five species of Achillea sect. Millefolium subsect. Filipendulinae (Compositae, Anthemideae). Willdenowia 1999, 29, 141-146. [CrossRef]

10. Demirel, M.A.; Suntar, I.; Ilhan, M.; Keles, H.; Kupeli Akkol, E. Experimental endometriosis remission in rats treated with Achillea biebersteinii Afan.: Histopathological evaluation and determination of cytokine levels. Eur. J. Obstet. Gynecol. Reprod. Biol. 2014, 175, 172-177. [CrossRef]

11. Akkol, E.K.; Koca, U.; Pesin, I.; Yilmazer, D. Evaluation of the Wound Healing Potential of Achillea biebersteinii Afan. (Asteraceae) by In Vivo Excision and Incision Models. Evid. Based. Complement. Alternat. Med. 2011, 2011, 39. [CrossRef]

12. Hormozi, M.; Baharvand, P. Achillea biebersteinni Afan may inhibit scar formation: In vitro study. Mol. Genet. Genom. Med. 2019, 7, 640. [CrossRef]

13. Erdogan, M.; Ağca, C.; Asskin, H. Achillea biebersteinii extracts suppress angiogenesis and enhance sensitivity to 5-fluorouracil of human colon cancer cells via the PTEN/AKT/mTOR pathway in vitro. Asian Pac. J. Trop. Biomed. 2020, 10, 505. [CrossRef]

14. Gaweł-Bęben, K.; Strzȩpek-Gomółka, M.; Czop, M.; Sakipova, Z.; Głowniak, K.; Kukula-Koch, W. Achillea millefolium L. and Achillea biebersteinii Afan. Hydroglycolic Extracts-Bioactive Ingredients for Cosmetic Use. Molecules 2020, 25, 3368. [CrossRef]

15. The Plant List. Available online: http://www.theplantlist.org (accessed on 1 April 2021).

16. Sadeer, N.B.; Montesano, D.; Albrizio, S.; Zengin, G.; Mahomoodally, M.F. The versatility of antioxidant assays in food science and safety-chemistry, applications, strengths, and limitations. Antioxidants 2020, 9, 709. [CrossRef] [PubMed]

17. Koushki, M.; Farrokhi Yekta, R.; Amiri-Dashatan, N.; Dadpay, M.; Goshadrou, F. Therapeutic effects of hydro-alcoholic extract of Achillea wilhelmsii C. Koch on indomethacin-induced gastric ulcer in rats: A proteomic and metabolomic approach. BMC Complement. Altern. Med. 2019, 19, 2623. [CrossRef] [PubMed]

18. Asgary, S.; Naderi, G.H.; Sarrafzadegan, N.; Mohammadifard, N.; Mostafavi, S.; Vakili, R. Antihypertensive and antihyperlipidemic effects of Achillea wilhelmsii. Drugs Exp. Clin. Res. 2000, 26, 89-93.

19. Ashtiani, M.; Nabatchian, F.; Galavi, H.R.; Saravani, R.; Farajian-Mashhadi, F.; Salimi, S. Effect of Achillea wilhelmsii extract on expression of the human telomerase reverse transcriptase mRNA in the PC3 prostate cancer cell line. Biomed. Rep. 2017, 7, 251-256. [CrossRef] [PubMed] 
20. Gevrenova, R.; Zengin, G.; Sinan, K.I.; Yıldıztugay, E.; Zheleva-Dimitrova, D.; Picot-Allain, C.; Mahomoodally, M.F.; Imran, M.; Dall'acqua, S. UHPLC-MS Characterization and Biological Insights of Different Solvent Extracts of Two Achillea Species (A. aleppica and A. santolinoides) from Turkey. Antioxidants 2021, 10, 1180. [CrossRef]

21. Albayrak, S.; Silahtarlığlu, N. Determination of biological activities of essential oil and extract obtained from Achillea coarctata Poir. Adv. Tradit. Med. 2020, 20,77-88. [CrossRef]

22. Smoylovska, G.P.; Mazulin, O.V.; Abramov, A.V.; Bukhtiyarova, N.V. Pharmacologic and toxicologic properties of lyophilic extract Achillea setacea Waldst. et Kit. Zaporozhye Med. J. 2017, 11, 5308. [CrossRef]

23. Ertaş, A.; Boğa, M.; Haşimi, N.; Yeşil, Y.; Gören, A.C.; Topçu, G.; Kolak, U. Antioxidant, anticholinesterase, and antimicrobial activities and fatty acid constituents of Achillea cappadocica Hausskn. et Bornm. Turk. J. Chem. 2014, 38, 592-599. [CrossRef]

24. Yener, I.; Yilmaz, M.A.; Olmez, O.T.; Akdeniz, M.; Tekin, F.; Hasimi, N.; Alkan, M.H.; Ozturk, M.; Ertas, A. A Detailed Biological and Chemical Investigation of Sixteen Achillea Species' Essential Oils via Chemometric Approach. Chem. Biodivers. 2020, 17, e1900484. [CrossRef] [PubMed]

25. Saeidi, K.; Moosavi, M.; Lorigooini, Z.; Maggi, F. Chemical characterization of the essential oil compositions and antioxidant activity from Iranian populations of Achillea wilhelmsii K.Koch. Ind. Crops Prod. 2018, 112, 274-280. [CrossRef]

26. Bessada, S.M.F.; Barreira, J.C.M.; Oliveira, M.B.P.P. Asteraceae species with most prominent bioactivity and their potential applications: A review. Ind. Crops Prod. 2015, 76, 604-615. [CrossRef]

27. Verma, R.S.; Joshi, N.; Padalia, R.C.; Goswami, P.; Singh, V.R.; Chauhan, A.; Verma, S.K.; Iqbal, H.; Verma, R.K.; Chanda, D.; et al. Chemical composition and allelopathic, antibacterial, antifungal and in vitro acetylcholinesterase inhibitory activities of yarrow (Achillea millefolium L.) native to India. Ind. Crops Prod. 2017, 104, 144-155. [CrossRef]

28. Yilmaz, M.A.; Ertas, A.; Yener, I.; Akdeniz, M.; Cakir, O.; Altun, M.; Demirtas, I.; Boga, M.; Temel, H. A comprehensive LC-MS/MS method validation for the quantitative investigation of 37 fingerprint phytochemicals in Achillea species: A detailed examination of A. coarctata and A. monocephala. J. Pharm. Biomed. Anal. 2018, 154, 413-424. [CrossRef]

29. Varasteh-kojourian, M.; Abrishamchi, P.; Matin, M.M.; Asili, J.; Ejtehadi, H.; Khosravitabar, F.; Antioxidant, K.F. Antioxidant, cytotoxic and DNA protective properties of Achillea eriophora DC. and Achillea biebersteinii Afan. extracts: A comparative study. Avicenna J. Phytomed. 2017, 7, 157. [CrossRef]

30. Şabanoğlu, S.; Gökbulut, A.; Altun, M.L. Characterization of phenolic compounds, total phenolic content and antioxidant activity of three Achillea species. Marmara Pharm. J. 2019, 23, 567-576. [CrossRef]

31. Farhadi, N.; Babaei, K.; Farsaraei, S.; Moghaddam, M.; Ghasemi Pirbalouti, A. Changes in essential oil compositions, total phenol, flavonoids and antioxidant capacity of Achillea millefolium at different growth stages. Ind. Crops Prod. 2020, 152, 2750. [CrossRef]

32. Apel, L.; Lorenz, P.; Urban, S.; Sauer, S.; Spring, O.; Stintzing, F.C.; Kammerer, D.R. Phytochemical characterization of different yarrow species (Achillea sp.) and investigations into their antimicrobial activity. Z. Fur. Naturforsch.-Sect. C J. Biosci. 2021, 76, 55-65. [CrossRef]

33. Agar, O.T.; Dikmen, M.; Ozturk, N.; Yilmaz, M.A.; Temel, H.; Turkmenoglu, F.P. Comparative Studies on Phenolic Composition, Antioxidant, Wound Healing and Cytotoxic Activities of Selected Achillea L. Species Growing in Turkey. Molecules 2015, 20, 17976. [CrossRef]

34. Zengin, G.; Aktumsek, A.; Ceylan, R.; Uysal, S.; Mocan, A.; Guler, G.O.; Mahomoodally, M.F.; Glamočlija, J.; Ćirić, A.; Soković, M. Shedding light on the biological and chemical fingerprints of three Achillea species (A. biebersteinii, A. millefolium and A. teretifolia). Food Funct. 2017, 8, 1152-1165. [CrossRef] [PubMed]

35. Huyut, Z.; Beydemir, Ş.; Gülçin, I. Antioxidant and antiradical properties of selected flavonoids and phenolic compounds. Biochem. Res. Int. 2017, 2017, 6791. [CrossRef] [PubMed]

36. Alcázar Magaña, A.; Kamimura, N.; Soumyanath, A.; Stevens, J.F.; Maier, C.S. Caffeoylquinic acids: Chemistry, biosynthesis, occurrence, analytical challenges, and bioactivity. Plant J. 2021, 107, 1299-1319. [CrossRef]

37. Strzępek-Gomółka, M.; Gaweł-Bęben, K.; Angelis, A.; Antosiewicz, B.; Sakipova, Z.; Kozhanova, K.; Głowniak, K.; Kukula-Koch, W. Identification of Mushroom and Murine Tyrosinase Inhibitors from Achillea biebersteinii Afan. Extract. Molecules 2021, $26,964$. [CrossRef] [PubMed]

38. Li, X.; Li, K.; Xie, H.; Xie, Y.; Li, Y.; Zhao, X.; Jiang, X.; Chen, D. Antioxidant and cytoprotective effects of the Di-O-Caffeoylquinic acid family: The mechanism, structure-activity relationship, and conformational effect. Molecules 2018, 23, 222. [CrossRef] [PubMed]

39. Salarbashi, D.; Fazly Bazzaz, B.S.; Sahebkar, A.; Karimkhani, M.M.; Ahmadi, A. Investigation of optimal extraction, antioxidant, and antimicrobial activities of Achillea biebersteinii and A. wilhelmsii. Pharm. Biol. 2012, 50, 1168-1176. [CrossRef]

40. Salarbashi, D.; Fazly Bazzaz, B.S.; Karimkhani, M.M.; Sabeti Noghabi, Z.; Khanzadeh, F.; Sahebkar, A. Oil stability index and biological activities of Achillea biebersteinii and Achillea wilhelmsii extracts as influenced by various ultrasound intensities. Ind. Crops Prod. 2014, 55, 163-172. [CrossRef]

41. Bariş, D.; Kizil, M.; Aytekin, C.; Kizil, G.; Yavuz, M.; Çeken, B.; Ertekin, A.S. In Vitro Antimicrobial and Antioxidant Activity of Ethanol Extract of Three Hypericum and Three Achillea Species From Turkey. Int. J. Food Prop. 2011, 14, 339-355. [CrossRef]

42. Tsimogiannis, D.I.; Oreopoulou, V. Free radical scavenging and antioxidant activity of 5,7,3' $4^{\prime}$-hydroxy-substituted flavonoids. Innov. Food Sci. Emerg. Technol. 2004, 5, 523-528. [CrossRef] 
43. Rutkowska, M.; Olszewska, M.A.; Kolodziejczyk-Czepas, J.; Nowak, P.; Owczarek, A. Sorbus domestica Leaf Extracts and Their Activity Markers: Antioxidant potential and synergy effects in scavenging assays of multiple oxidants. Molecules 2019, $24,2289$. [CrossRef]

44. Abd-Alla, H.I.; Shalaby, N.M.M.; Hamed, M.A.; El-Rigal, N.S.; Al-Ghamdi, S.N.; Bouajila, J. Phytochemical composition, protective and therapeutic effect on gastric ulcer and $\alpha$-amylase inhibitory activity of Achillea biebersteinii Afan. Arch. Pharm. Res. 2016, 39, 10-20. [CrossRef]

45. Omosa, L.K.; Amugune, B.; Ndunda, B.; Milugo, T.K.; Heydenreich, M.; Yenesew, A.; Midiwo, J.O. Antimicrobial flavonoids and diterpenoids from Dodonaea angustifolia. South Afr. J. Bot. 2014, 91, 58-62. [CrossRef]

46. Williams, C.A.; Greenham, J.; Harborne, J.B. The role of lipophilic and polar flavonoids in the classification of temperate members of the Anthemideae. Biochem. Syst. Ecol. 2001, 29, 929-945. [CrossRef]

47. Zidorn, C. Guidelines for consistent characterisation and documentation of plant source materials for studies in phytochemistry and phytopharmacology. Phytochemistry 2017, 139, 56-59. [CrossRef]

48. Padilla-González, G.F.; Frey, M.; Gómez-Zeledón, J.; Da Costa, F.B.; Spring, O. Metabolomic and gene expression approaches reveal the developmental and environmental regulation of the secondary metabolism of yacón (Smallanthus sonchifolius, Asteraceae). Sci. Rep. 2019, 9, 9246. [CrossRef]

49. Iwanycki Ahlstrand, N.; Havskov Reghev, N.; Markussen, B.; Bruun Hansen, H.C.; Eiriksson, F.F.; Thorsteinsdóttir, M.; Rønsted, N.; Barnes, C.J. Untargeted metabolic profiling reveals geography as the strongest predictor of metabolic phenotypes of a cosmopolitan weed. Ecol. Evol. 2018, 8, 6812-6826. [CrossRef]

50. Moore, B.D.; Andrew, R.L.; Külheim, C.; Foley, W.J. Explaining intraspecific diversity in plant secondary metabolites in an ecological context. New Phytol. 2014, 201, 733-750. [CrossRef] [PubMed]

51. Zidorn, C. Plant chemophenetics-A new term for plant chemosystematics/plant chemotaxonomy in the macro-molecular era. Phytochemistry 2019, 2, 13. [CrossRef] [PubMed]

52. Arabaci, T. Revision of Achillea L. (Asteraceae) Genus Grown in Turkey; Nonu University, Institute of Sciences and Technology: Malatya, Turkey, 2006

53. Re, R.; Pellegrini, N.; Proteggente, A.; Pannala, A.; Yang, M.; Rice-Evans, C. Antioxidant activity applying an improved ABTS radical cation decolorization assay. Free Radic. Biol. Med. 1999, 26, 1231-1237. [CrossRef]

54. Raudone, L.; Vilkickyte, G.; Pitkauskaite, L.; Raudonis, R.; Vainoriene, R.; Motiekaityte, V.; Raudone, L.; Vilkickyte, G.; Pitkauskaite, L.; Raudonis, R.; et al. Antioxidant Activities of Vaccinium vitis-idaea L. Leaves within Cultivars and Their Phenolic Compounds. Molecules 2019, 24, 844. [CrossRef]

55. Vilkickyte, G.; Raudone, L.; Petrikaite, V. Phenolic fractions from vaccinium vitis-idaea l. And their antioxidant and anticancer activities assessment. Antioxidants 2020, 9, 1261. [CrossRef]

56. EMEA. ICH Topic Q2 (R1), Validation of Analytical Procedures: Text and Methodology; European Medicines Agency: London, UK, 2005. 